Western University Scholarship@Western

Centre for the Study of International Economic

Centre for the Study of International Economic

Relations Working Papers

Relations

1980

\title{
The Welfare and Allocative Effects of Export Taxes versus Marketing Boards
}

James R. Markusen

Follow this and additional works at: https://ir.lib.uwo.ca/economicscsier_wp

Part of the Economics Commons

Citation of this paper:

Markusen, James R.. "The Welfare and Allocative Effects of Export Taxes versus Marketing Boards." Centre for the Study of International Economic Relations Working Papers, 8022. London, ON: Department of Economics, University of Western Ontario (1980). 
CENTRE FOR THE STUDY OF INTERNATIONAL ECONOMIC RELATIONS

WORKING PAPER NO. 8022

THE WELFARE AND ALLOCATIVE EFFECTS

OF EXPORT TAXES VERSUS MARKETING BOARDS

James R. Markusen

This paper contains preliminary findings from research work still in progress and should not be quoted withour prior approval of the author.

DEPARTMENT OF ECONOMICS UNIVERSITY OF WESTERN ONTARIO LONDON, CANADA N6B $2 Z 3$
Department of Economics Library

DEC 121980

University of Western Ontario 
DEC 121980

Univerity of Hesteri Ontario

THE WELFARE AND ALLOCATIVE EFFECTS

OF EXPORT TAXES VERSUS MARKETING BOARDS*

\author{
James $\cdot R$. Markusen \\ Department of Economics \\ University of Western Ontario \\ and \\ Department of Economics \\ University of New South Wales
}

\title{
Abstract
}

Three types of export marketing boards are compared to the traditional optimal export tax:

(A) A board that cannot price discriminate between domestic and foreign customers;

(B) A board that can discriminate, and

(C) A board that is constrained by domestic marginal-cost pricing. While all three types produce allocations inferior to the optimal export tax, type (C) is at least always superior to free trade. Adopting a "mini-max" attitude, the policy ranking is (1) export tax, (2) board type (C), (3) free trade, and (4) board types (A) and (B).

First Draft, November, 1980.

*the author would like to thank Murray Kemp for helpful comments and suggestions. 
I. Introduction.

The notion that a country with influence over world prices can Improve its welfare via import and/or export taxes is an Idea that goes back as far as Bickerdike (1906). Following Blckerdike, formulae for the optimal 1mport or export tax have been proposed and refined by Graaf (1949), Johnson (1954), Jones (1967), and Kemp (1969). Yet export taxes are not of ten observed (Auquier and Caves (1979)) and import tariffs do not seem to be instituted primarily to exploit monopoly power in trade. We have, however, recently witnessed a growth in export marketing boards which might at first glance seem to perform roughly the same function as an optimal export tax. The purpose of this paper is to examine these marketing boards and compare them to the optimal export taxes developed in the trade theory 1iterature. Marketing boards, especially for agricultural and other primary products, are common in Canada, Australia, Europe, and in many developing countries. These boards do however differ both in their objectives and in the constraints they face. On the one hand, a marketing board could concelvably be directed to maximize some social welfare function. In this case, there will be no allocative differences between the marketing board and an optimal export tax. Distributional differences could of course exist depending on how the marketing board disposed of its profits. The more interesting situation would seem to be the case in which the marketing board is directed to maximize profits either on behalf of individual producers or on behalf of the government treasury.

Throughout this paper, we will concentrate on this profitmaximizing behaviour and neglect the tax-equivalent case of welfare maximization. The following section develops a two-good, generalequilibrium model in order to compare a social-welfare-maximizing, 
optimal-export-tax equilibrium (henceforth SW equilibrium) to several marketing-board equilibria. ${ }^{1}$

Three versions of the marketing board problem are considered. First, it is assumed that the marketing board cannot price discriminate between domestic and foreign buyers (e.g., it cannot prevent international arbitrage). This will be referred to as the MN equilibrium. Second, it is assumed that the marketing board is free to discriminate between domestic and foreign customers (henceforth the MD equilibrium). Third, it is assumed that the marketing board can set any foreign price (subject of course to foreign demand) but is constrained by marginalcost pricing at home (henceforth the MM equilibrium). This constraint could arise for either of two reasons:

A. individual producers are free to sell domestically without going through the marketing board (1.e., there is domestic competition) or B. the government imposes domestic marginal-cost pricing as a regulatory constraint. 2

Several results emerge concerning social welfare, which is defined in terms of community indifference curves or revealed preference criteria (i.e., distributional considerations are either ignored or are assumed to be the domain of domestic taxation policy). F1rst, all three marketing board equilibrla involve a lower level of social welfare relative to the SW equilibrium. This is certainly not surprising with respect to the MN and $M D$ equilibria. But it is, I think, a bit surprising for the MM case insofar as the marketing board is apparently acting as a competitor in domestic markets and as a monopolist in foreign markets. Th1s result thus suggests that choosing prices subject to a marginalcost pricing constraint is not the same thing as behaving as a price taker, given the ability to shift supply into or out of a second market. 
Second, it is noted that the MN and MD equilibria may involve a level of social welfare which is less than the level which would prevail In competitive free trade (no marketing board). Indeed, it follows from Markusen (1980b) and Markusen and Melvin (1981) that the MN and MD. equilibria could even involve losses relative to autarky. ${ }^{3}$ Third, it is shown that the MM equilibrium must involve a level of welfare somewhere between the soclal-welfare-optimum level and the free-trade level of welfare. Thus only in the MM case can we be assured of gains from trade and gains from the marketing board system.

Results concerning production of the export good are that the $M D$ equilibrium will involve less production and the MM equilibrium more production than the SW equilibrium production level. The MN production level can lie on either side of the SW production level, but will always involve less than the SW production level if foreign demand is relatively more elastic than domestic demand. ${ }^{4}$ One relevant feature' of these production differences has to do with forelgn welfare. From production levels we are able to deduce the equilibrium level of the terms of trade which is in turn monotonically related to foreign welfare. It is shown that the $M D$ and $M$ M equilibria involve a lower world price for the domestic export good and thus a higher level of foreign welfare relative to the SW equilibrium. These two types of marketing boards thus Involve an income transfer to forelgners relative to the optimal export tax. Only the $M N$ board can Involve an improvement in the terms of trade and a loss in foreign welfare relative to the social optimum. In such a situation, both countries are worse off relative to the SW equilibrium. 
The paper concludes with a short section on forelgn retaliation and collusion. It is noted that if two countries both behave in a symmetric, Cournot-Nash fashion, then the MM equilibrium will in fact improve world real income (although not necessarily the real income of both countries) relative to the SW equilibrium. On the other hand, two collusive marketing boards will produce an equilibrium inferior to the equilibrium produced by two "collusive" or cooperative welfaremaximizing governments. 
II. The Social Welfare Optimum

The country in question is assumed to produce and trade two goods $\left(x_{0}\right.$ and $x_{1}$ ) from factors in fixed and inelastic supply. Consumption quantities of $X_{0}$ and $X_{1}$ are denoted $C_{0}$ and $C_{1}$ respectively. $p$ will denote the domestic price of $x_{1}$ in terms of $x_{0}$ and $p^{*}$ will denote the world trading price of $x_{1}$ in terms of $x_{0} \cdot x_{1}$ is assumed to be the domestic export good.

Following Jones (1967), Vandendorpe (1972), and Markusen and Melvin (1979), it is assumed that demand conditions can be represented by a set of community indifference curves, so that the social welfare function and its total differential are given as follows:

$$
\mathrm{U}=\mathrm{U}\left(\mathrm{C}_{0}, \mathrm{C}_{1}\right), \frac{\mathrm{dU}}{\mathrm{U}_{0}}=\mathrm{dC}_{0}+\frac{\mathrm{U}_{1}}{\mathrm{U}_{0}} \mathrm{dC_{1 }}=\mathrm{dC}_{0}+\mathrm{pdC}_{1} .
$$

As noted above, welfare is assumed to be a function of aggregate consumption only. $d U / U_{0}$ is the change in income in terms of $C_{0}$ and will henceforth be denoted.dy. $p$ will equal the marginal rate of substitution $\left(\mathrm{U}_{1} / \mathrm{U}_{0}\right)$ as per the usual competitive assumptions.

With factors in inelastic supply, the aggregate transformation function and its differential are given as follows:

$$
X_{0}=F\left(X_{1}\right), \quad d X_{0}-F^{\prime} d X_{1}=0 ; \quad F^{\prime}, F^{\prime \prime}<0 .
$$

Equation (2) embodies the assumption that factor markets are competitive and that no monopsony distortions occur (Melvin and Warne,(1973), and Markusen $(1980 \mathrm{a}, 1980 \mathrm{~b}))$. $-\mathrm{F}^{\prime}$ is the marginal rate of transformation along the efficient production frontier.

The balance of payments constraint and its differential are given by

$$
e_{0}+p * e_{1}=0, e_{1}=x_{1}-c_{1}, d e_{0}+p * d e_{1}+e_{1} d p *=0
$$

$e_{1}$ is thus domestic excess supply or foreign excess demand. $e_{1}>0$ by assumption. 
Let $\theta$ denote the percentage distortion between $\mathrm{p}^{*}$ and $\mathrm{F}^{\prime}$ (the MRT) and $T$ denote the percentage distortion between $p$ and $F^{\prime}$. Price relationships are then given by

$$
p^{*}(1-\theta)=p(1-T)=-F^{\prime}
$$

The domestic trading opportunities can be summarized by the foreign offer curve, which gives excess demands as functions of prices. Since the relevant information can be summarlzed in terms of either good by virtue of the balance of payments constraint, the foreign curve is simply specified es follows:

$$
e_{1}=E\left(p^{*}\right), \quad d e_{1}=E_{p} d p^{*}, \quad E_{p}=\frac{\partial e}{\partial p^{*}}<0
$$

As noted in (5), it is assumed throughout the paper that foreign excess demand for $x_{1}$ (domestic excess supply) is negatively related to the world price ratio. Derivations of this offer curve from underlying demand and supply parameters can be found in Jones (1967), Markusen and Melvin (1979), and Markusen (1981). In the last section of the paper we will consider a more complicated version of (5) in which foreign excess demand depends on foreign taxes or price distortions as well. Following Vandendorpe (1972), $C_{1}$ may be defined as a function of $p$ and $y$.

$$
C_{1}=D(p, y), \quad d C_{1}=D_{p} d p+D_{y} d y, \quad D_{p}<0, D_{y}>0
$$

$D_{y}>0$ provided that $C_{1}$ is a normal good. Combining (6) and (5) with the 1dentity $x_{i}=e_{1}+C_{i}$, we also have

$$
\begin{aligned}
& d x_{1}=d e_{1}+d C_{1}=E_{p} d p^{*}+D_{p} d p+D_{y} d y . \\
& \text { Substituting } d x_{1}-d e_{i} \text { for } d C_{1} \text { in the welfare differential (1), }
\end{aligned}
$$
we have

$$
d y=d C_{0}+p d C_{1}=d x_{0}-d e_{0}+p d x_{1}-p d e_{1}
$$


Substituting for $\mathrm{dx}_{0}$ and $\mathrm{de}_{0}$ from equations (2) and (3) respectively, we have

$$
\begin{aligned}
d y & =F^{\prime} d X_{1}+p d X_{1}+p * d e_{1}+e_{1} d p^{*}-p d e_{1} \\
& =\left(P+F^{\prime}\right) d X_{1}+(p *-p) E_{p} d p^{*}+e_{1} d p^{*} .
\end{aligned}
$$

Substituting from (4) then gives

$$
d y=(p T) d x_{1}+\left((p * \theta-p T) E_{p}+e_{1}\right) d p *
$$

Optimality requires us to choose $\theta$ and $T$ such that (10) is zero for all differentials $d x_{1}$ and $d p *$.

$$
\text { dy }=0 \text { implies } \mathrm{T}=0, \quad \theta=-\frac{e_{1}}{\mathrm{p}^{*} \mathrm{E}_{\mathrm{p}}}=1 / \eta_{\mathrm{e}}^{*}>0
$$

Optimality thus requires that the domestic price ratio equal the MRT and requires an export $\operatorname{tax}(\theta)$ equal to the inverse of the foreign elasticity of excess demand, denoted by $n_{e}^{*}$. As noted earlier, this formula goes back to Bickerdike and Graaff. For the remainder of the paper, we will assume that $\eta_{e}^{*}$ is a constant. This constant elasticity assumption, introduced by Johnson (1954) and Gorman (1958), facilitates the comparison of the various equilbria.

The SW equilibrium is contrasted with the free trade equilibrium In Figure I. Free trade production and consumption are at $A$ and $A^{\prime}$ respectively. The soctal-welfare-optimum levels of production and consumption are at points $S$ and $S^{\prime}$. As noted in (11), the consumer price ratio at $S^{\prime}$ (the slope of $U_{S}$ ) is equal to the slope of the transformation function at $S$. As per the usual textbook analysis, the export tax improves domestic welfare by shifting the world price ratio in favour of the domestic export good. 
FIGURE I

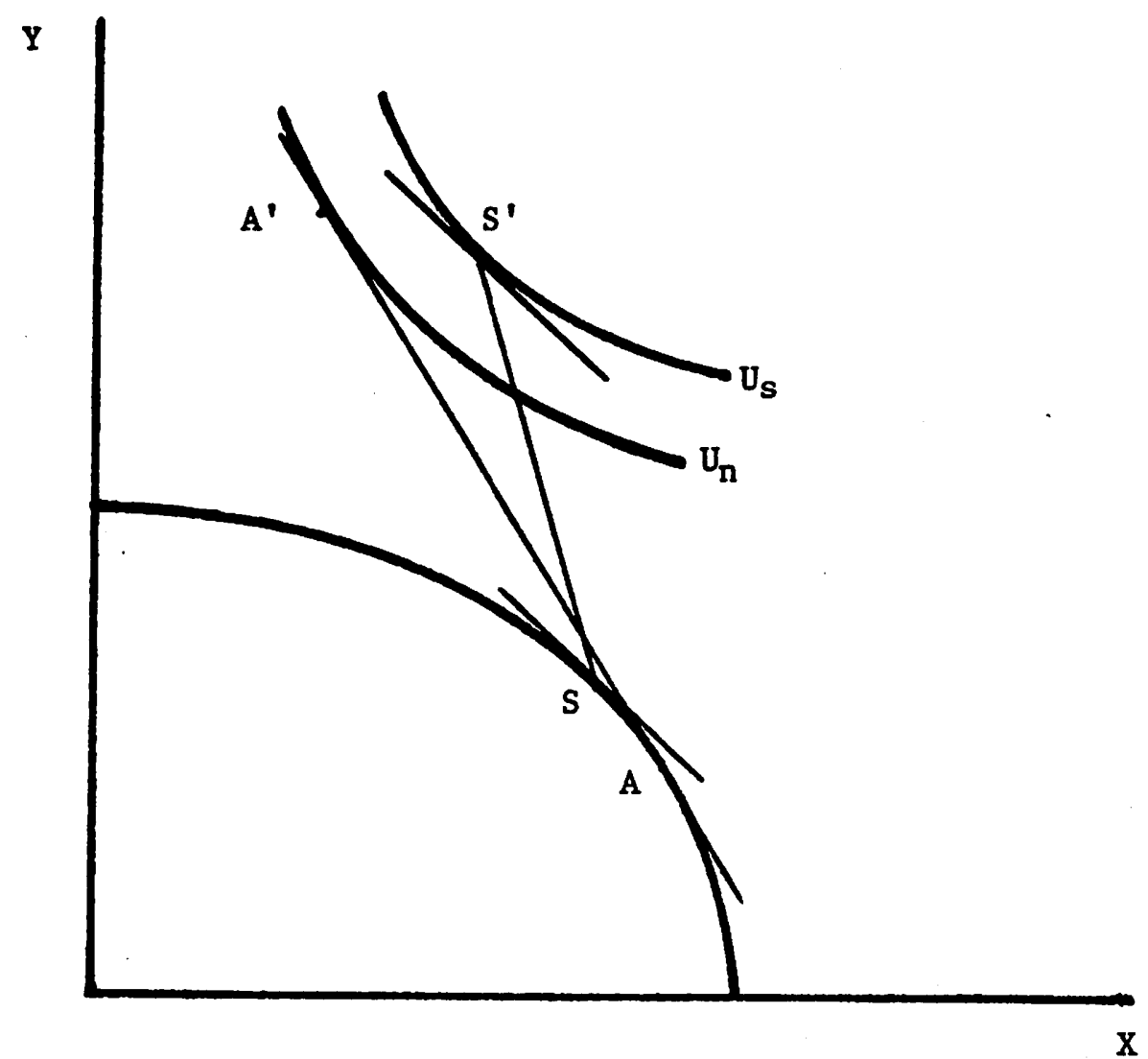

FIGURE II

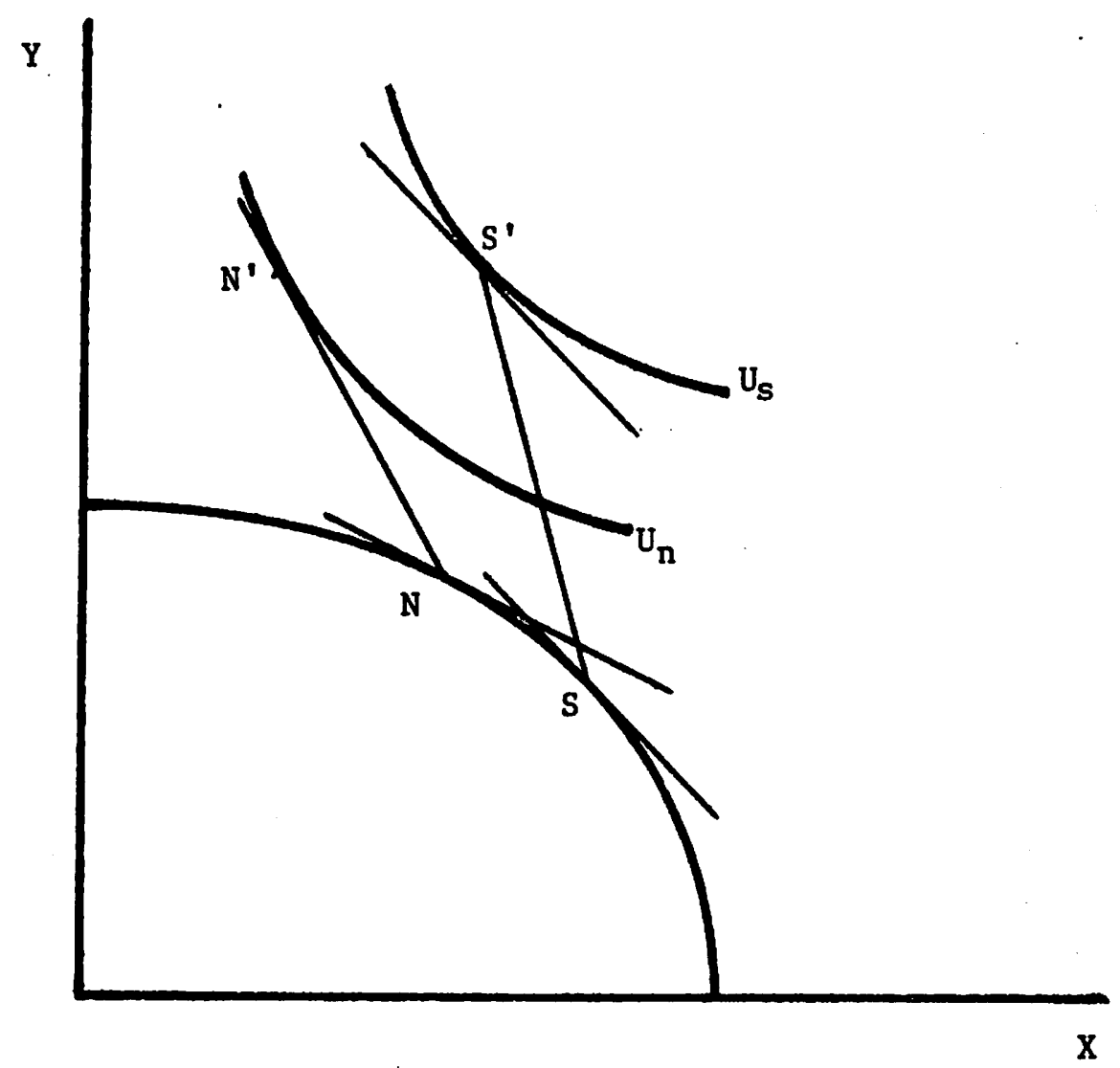


III. Marketing Board - Price Discrimination not Permitted

As noted earlier, it is assumed that the objective of a narketing board is to maximize profits. In the present case, it is assumed that the board cannot discriminate between domestic and foreign customers so that $p=p *$ or $T=\theta$. Since the social optimum requires $p<p *$, it is immediately apparent that the marketing board cannot produce a first-best optimum. Denoting the cost of producing $x_{1}$ in terms of $x_{0}$ as $c\left(x_{1}\right)$, the marketing board's problem is as follows ( $\pi$ denotes profits):

$$
\text { Maximize } \pi=p * X_{1}-C\left(X_{1}\right) \text { where } p=p * \text { or } T=\theta \text {. }
$$

$C^{\prime}(x)$, the marginal cost of $x_{1}$ in terms of $x_{0}$, will equal $-F(X)$. Differentiating (12) and substituting for $x_{1}$ from (7), we have

$$
\begin{aligned}
d \pi & =p * d X_{1}+X_{1} d p *-C^{\prime}(X) d X_{1} \text {, and from }(7) \\
& =p^{*}\left(E_{p}+D_{p}\right) d p *+p^{*} D_{y} d y+x_{1} d p^{*}+F^{\prime}\left(E_{p}+D_{p}\right) d p *+F^{\prime} D_{y} d y \\
& =\left(p *+F^{\prime}\right)\left(E_{p}+D_{p}\right) d p *+\left(p^{*}+F^{\prime}\right) D_{y} d y+X_{1} d p * \\
& =(p * T)\left(E_{p}+D_{p}\right) d p *+(p * T) D_{y} d y+x_{1} d p *
\end{aligned}
$$

Given that $\mathrm{T}=\theta$, dy is given in (10).

$$
\begin{aligned}
d y & =p * T d X_{1}+e_{1} d p^{*}, \text { and from }(7), \\
& =p * T D_{y} d y+p * T\left(E_{p}+D_{p}\right) d p *+e_{1} d p^{*} .
\end{aligned}
$$

Solving out for dy, we have

$$
d y=\left(1-p * T D_{y}\right)^{-1}\left(p * T\left(E_{p}+D_{p}\right)+e_{1}\right) d p *=A d p *
$$

where A may be either positive or negative depending upon the strengths of income and substitution effects. Substituting (15) into (13), we have

$$
d \pi=(p * T)\left(E_{p}+D_{p}+D_{y} A\right) d p *+x_{1} d p *
$$

The profit maximizing level of $T$ is found by setting $d \pi$ equal to zero for all levels of $d p^{*}$. 


$$
d \pi=0 \text { implies } T=\theta=-\frac{x_{1}}{p^{*}\left(E_{p}+D_{p}+D_{y} A\right)}=1 / \eta_{\omega}
$$

where $\eta_{\omega}$ is the "world" elasticity of demand facting the marketing board (the elasticity of domestic demand.plus foreign excess demand). $\eta_{\omega}$ can be expanded as follows:

$$
\begin{aligned}
-n_{\omega} & =\frac{p^{*}}{c_{1}+e_{1}} \frac{d\left(c_{1}+e_{1}\right)}{d p^{*}}=\frac{p^{*}}{c_{1}+e_{1}} \frac{d c_{1}}{d p^{*}}+\frac{p^{*}}{c_{1}+e_{1}} \frac{d e_{1}}{d p^{*}} \\
n_{\omega} & =\left(\frac{c_{1}}{c_{1}+e_{1}}\right) n_{d^{*}}+\left(\frac{e_{1}}{c_{1}+e_{1}}\right) n_{e^{*}}, \quad n_{d}=-\frac{p^{*}\left(D_{p}+D_{y} A\right)}{c_{1}}
\end{aligned}
$$

$\eta_{w}$ is thus the convex combination of $\eta_{d}$ (the domestic elasticity of demand) and $n_{e}^{*}$, where the weights are respective shares of domestic consumption and exports in total domestic production $\left(c_{1}+e_{1}\right)_{2}$. The elasticities in (19) bear the following relationship to one another:

$$
\eta_{\omega}<\eta_{e}^{*} \text { if and only if } \eta_{d}<\eta_{e}^{*}
$$

Given the assumption that $\eta_{e}^{*}$ is a constant, it then follows from (17) that the marketing board's profit-maximizing distortion between $\mathrm{p}^{*}$ and MRT is greater than the socially optimal distortion if and only if $\eta_{d}<\eta_{e}^{*}$ (domestic demand is less elastic than foreign excess demand). Figure II shows the case in which $\eta_{d} \leq \eta_{e}^{*}, S$ and $S^{\prime}$ continue to denote the SW production and consumption levels while $N$ and $N$ ' denote the MN production and consumption levels. N' involves a tangency between a domestic indifference curve and the world price ratio by virtue of the constraint $p^{2} p^{*}$. In order to see that the production of $X$ at $N$ must be less than production at $S$, consider first the case in which $\eta_{d}=\eta_{e}^{*}$, so that the desired distortion between the world price ratio and the MRT is the same in the MN equilibrium as in the SW equilibrium.

Suppose initially that the marketing board attempted to produce at $S$, and at the world price ratio joining $S$ and $S^{\prime}$. Since domestic consumers are able to consume at the world price ratio in the MN equilibrium, 
point S' cannot be the consumer's equilibrium. Consumers will move to a point above $S^{\prime}$ where an indifference curve 18 tangent to the price ratio through $S$ and $S^{\prime}$. But this involves a higher import demand relative to $S^{\prime}$ and, given our assumptions about foreign demand, leads to a deterioration In the terms of trade. This leaves the "wedge" between $p *$ and $-F^{\prime}$ smaller than the desired wedge as given in (17). Production must move to a point like $N$ in order to lower $-F^{\prime}$, improve the terms of trade, and thus reestablish the optimal distortion. The same movement up the production frontler from $S$ will occur when $n_{d}<n_{e}^{*}$ by virtue of the fact that the desired distortion must exceed the SW distortion at S. A necessary but not sufficient condition for $X$ to be higher at the $M N$ equilibrium relative to $s$ is that $\eta_{d}>n_{e}^{*} .^{5}$

While the relation between $\eta_{d}$ and $\eta_{e}$ is an empirical matter, the case presented in Figure II $\left(n_{d} \leq n_{e}^{*}\right)$ may be the most relevant for two reasons. First, the domestic market may be small relative to the world market. Second; $\eta_{e}^{*}$ is an excess demand elasticity while $\eta_{d}$ is a simple demand elasticity. $n_{e}^{*}$ thus embodies a supply response which compliments the demand response (a price increase reduces foreign demand and increases foreign supply).

Finally, note that the MN board does not necessarily lead to a deterioration in the terms of trade relative to the SW equilibrium as is the case in Figure II. With domestic demand quite Inelastic, Figure II could easily be redrawn with the price ratio connecting $N$ and $N$ ' steeper than the price ratio connecting $S$ and $S^{\prime}$. 


\section{Marketing Board - Price Discrimination Permitted}

Now consider the case in which the marketing board is free to charge different prices to domestic and foreign customers. Since this will once again Imply that the domestic price will not equal the domestic MRT, it w11l not result in a social welfare optimum. The marketing board's problem is given as follows:

$$
\text { Maximize } \pi=\mathrm{pC}_{1}+\mathrm{p}^{*} \mathrm{e}_{1}-\mathrm{c}\left(\mathrm{x}_{1}\right), \mathrm{x}_{1}=\mathrm{C}_{1}+\mathrm{e}_{1}
$$

Differentiating, we have

$$
\begin{aligned}
d \pi & =p d C_{1}+C_{1} d p+p * d e_{1}+e_{1} d p^{*}+F^{\prime} d X_{1} \text { and from }(7), \\
& =\left(p+F^{\prime}\right)\left(D_{p} d p+D_{y} d y\right)+C_{1} d p+\left(p^{*}+F^{\prime}\right) E_{p}^{\prime} d p^{*}+e_{1} d p^{*} \\
& =(p T)\left(D_{p} d p+D_{y} d y\right)+C_{1} d p+\left(p * \theta E_{p}+e_{1}\right) d p *
\end{aligned}
$$

the change in income dy, is given in (10).

$$
\begin{aligned}
d y & =(p T) d x_{1}+(p * \theta-p T) E_{p} d p *+e_{1} d p^{*} \\
& =(p T)\left(d x_{1}-E_{p} d p^{*}\right)+\left(p * \theta E_{p}+e_{1}\right) d p * \text { and from }(7), \\
& =(p T)\left(E_{p} d p *+D_{p} d p+D_{y} d y-E_{p} d p *\right)+\left(p * \theta E_{p}+e_{1}\right) d p * \\
& =(p T)\left(D_{p} d p+D_{y} d y\right)+\left(p * \theta E_{p}+e_{1}\right) d p^{*} .
\end{aligned}
$$

Solving out for dy, (22) becomes

$$
\begin{aligned}
d y & =\left(1-p T D_{y}\right)^{-1}\left(p D_{p}\right) d p+\left(1-p T D_{y}\right)^{-1}\left(p * \theta E_{p}+e_{1}\right) d p * \\
& =B d p+\left(1-p T D_{y}\right)^{-1}\left(p * \theta E_{p}+e_{1}\right) d p *
\end{aligned}
$$

Equation (23) is not the same as (15) by virtue of the fact that $t \neq \theta$ and dpłdp*. Substituting (23) into (21), we have

$$
d \pi=(p T)\left(D_{p}+D_{y} B\right) d p+C_{1} d p+\left(1+\left(1-p T D_{y}\right)^{-1}\right)\left(p * \theta E_{p}+e_{1}\right) d p *
$$

Setting (24) equal to zero for all differentials dp and dp* gives the optimal domestic and forelgn distortions. 


$$
\theta=-\frac{e_{1}}{p^{* E} E_{p}}=1 / \eta_{e}^{*}, \quad T=-\frac{C_{1}}{p\left(D_{p}+D_{y} B\right)}=1 / n_{d}
$$

The profit maximizing value of $\theta$ is thus the same as the SW value, assumed to be a constant. The profit-maximizing domestic distortion 18 equal to $1 / \eta_{d}$, where $\eta_{d}$ takes on a somewhat different formula than $\eta_{d}$ in equation (19) $(A \neq B)$. Due to the fact that $p=p *$ in one case but not in the other, the income effect of a change in $p$ is not the same in the two cases. This difference is however of no qualitative importance.

Figure III shows the MD equilibrium production and consumption points $D$ and $D^{\prime}$ in relation to the SW equilibrium levels $S$ and $S^{\prime}$. In the present case, D must involve a lower level of $\mathrm{X}$ production relative to $S$ regardless of the relationship between $\eta_{d}$ and $\eta_{e}^{*}$. As noted in (25), the $M D$ distortion between $p^{*}$ and $-F^{\prime}$ is the same as the SW distortion given the assumption that $n_{e}^{*}$ is a constant. But if the marketing board were to produce at $S$, consumers would not be in equilibrium at $S^{\prime}$ since (25) requires $p^{\prime}-F^{\prime}$ while $p=-F^{\prime}$ at $S$. Consumers would move to a point above $S^{\prime}$ and thereby deterioriate the terms of trade. This deterioration would reduce the wedge between $\mathrm{p}^{*}$ and $-\mathrm{F}^{\prime}$ and would require the marketing board to move to a production point like $D$ in order to restore the wedge to its profit maximizing level.

The particular consumer equilibrium shown in Figure III is the case in which $\eta_{d}<\eta_{e}^{*}$ In such a situation $T>\theta$ and $p_{p} p^{*}$ as shown in (25). In the chance case that $\eta_{d}=\eta_{e}^{*}, p^{x} p^{*}$ and Figure III would be drawn Identical to Figure II.

Before moving to the next case it might be important to note that either the MN or MD equilibria may Involve a level of welfare which is lower than the free trade welfare level. This possibility 18, I think, implicit in the work of Melvin (1970), Markusen and Melvin (1981), and Markusen (1980b). The possibility can in fact be proved for the MD 
equilibrium by considering the case in which $\eta_{e}^{*}=\infty$, so that the optimal export tax is zero (free trade 1s the social welfare optimum). In this case, the MD equilibrium will involve a domestic distortion. as: shown in (25) ( $\theta$ will however be zero). It in fact follows from Melvin: (1970) that this MD equilibrium may Involve a level of welfare which is below the autarky level. 


\section{FIGURE III}

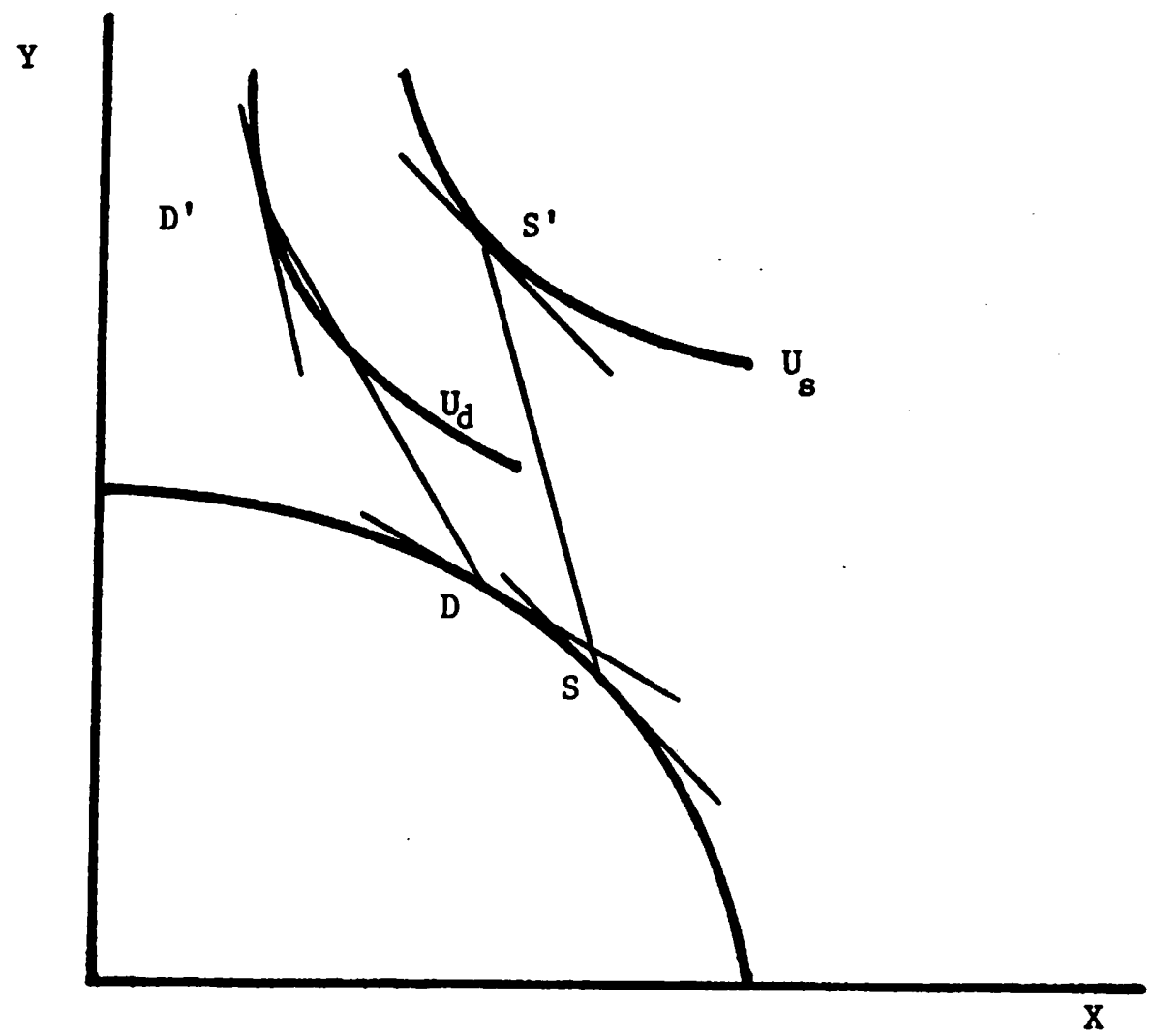

FIGURE IV

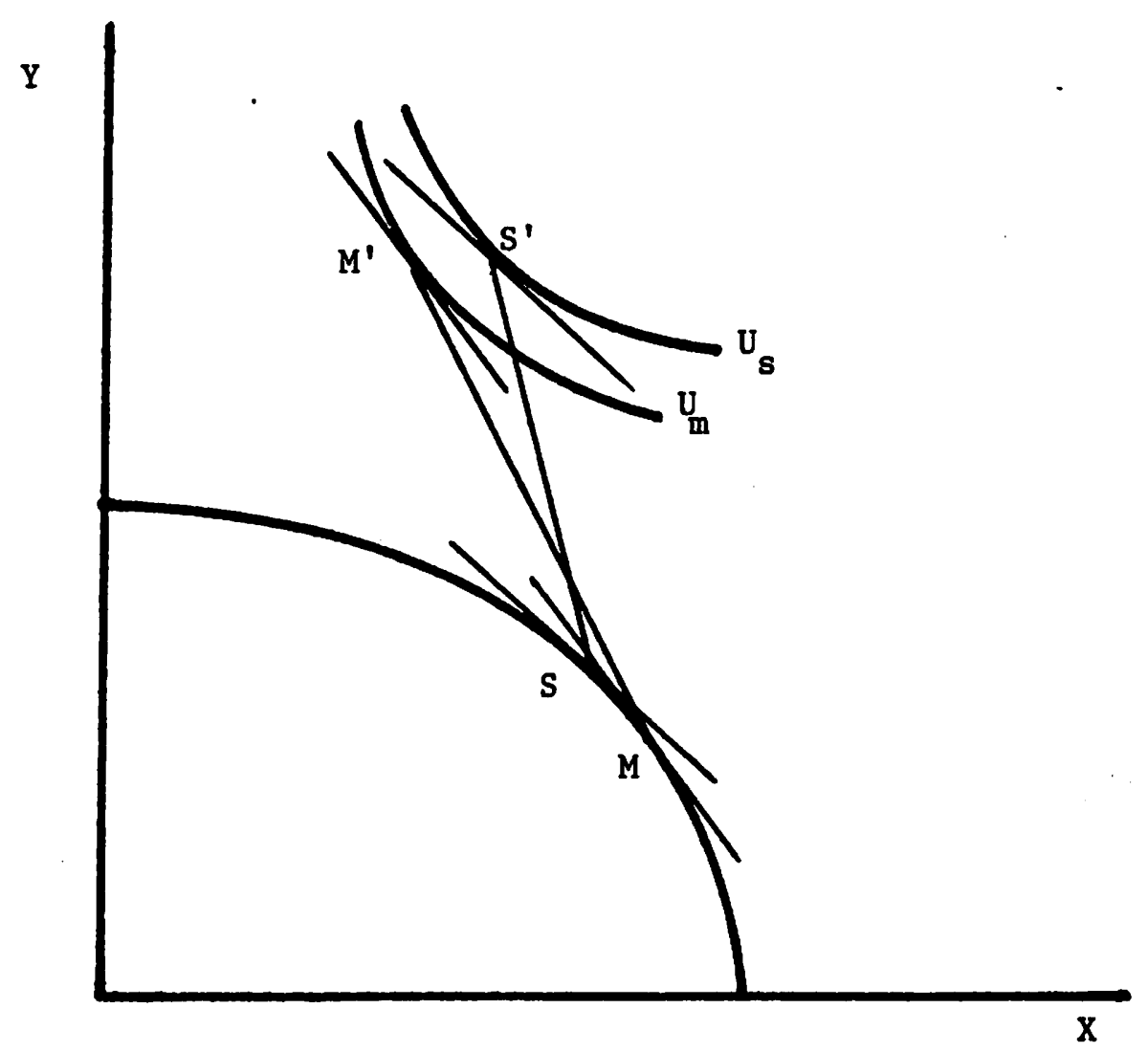




\section{v. Marketing Board - Domestic Marginal-Cost Pricing}

Finally we will consider the case in which the marketing board faces a domestic marginal-cost pricing constraint. As noted above, this constraint could be due to government regulation or to domestic competition among producers; that 1s, the marketing board controls only foreign sales. The marketing board's programing problem is now given as follows:

$$
\text { Maximize } \pi=P C_{1}+p^{*} C_{1}-C(X) \text { subject to } p=-F^{\prime} \text {. }
$$

Differentiating, we have

$$
\begin{aligned}
d \pi= & p d C_{1}+C_{1} d p+p^{*} d e_{1}+e_{1} d p^{*}+F^{\prime} d X_{1} \\
= & p D_{p} d p+p D_{y} d y+C_{1} d p+p^{*} E_{p} d p^{*}+e_{1} d p^{*} \\
& \quad+F^{\prime} D_{p} d p+F^{\prime} d_{y} d y+F^{\prime} E_{p} d p^{*} \\
= & C_{1} d p+\left(p^{*}+F^{\prime}\right) E_{p} d p^{*}+e_{1} d p^{*} \quad \text { Since } p=-F^{\prime} . \\
= & C_{1} d p+\left(p^{*} \theta E_{p}+e_{1}\right) d p^{*} .
\end{aligned}
$$

From this last line of (27), we see that profits will not be maximized by simply setting $\theta=1 / \eta_{e}^{*}$, and thus the profit maximizing solution will not be the social optimum. With $T$ constrained to equal zero, dy is given in (10).

$$
d y=\left(p * \theta E_{p}+e_{1}\right) d p *
$$

Since $p=-F^{\prime}, d C_{1}$ and $d x_{1}$ are given as follows:

$$
d C_{1}=D_{p} d p+D_{y} d y, d x_{1}=\left(-F^{\prime \prime}\right)^{-1} d p \text {. }
$$

Subtracting $d C_{1}$ from $d x_{1}$, we have

$$
d e_{1}=\left[\left(-F^{\prime \prime}\right)^{-1}-D_{p}\right] d p-D_{y} d y .
$$

Inverting (30) gives us an expression for dp.

$$
\begin{aligned}
d p & =\left[\left(-F^{\prime \prime}\right)^{-1}-D_{p}\right]^{-1} d_{1}+D_{y}\left[\left(-F^{\prime \prime}\right)^{-1}-D_{p}\right]^{-1} d y \\
& =G d e_{1}+D_{y} G d y . \quad G>0 .
\end{aligned}
$$


G is strictly positive by virtue of the facts that the production set is strictly convex $\left(F^{\prime \prime}<0\right.$ ) and that $G$ is a decreasing function of price, real income held constant $\left(D_{p}<0\right)$. Substituting the expression for dy in (28) into (31), and then substituting the resulting expression for dp into (27), we have

$$
d \pi=C_{1} G d e_{1}+C_{1} D_{y} G\left(p * \theta E_{p}+e_{1}\right) d p *+\left(p * \theta E_{p}+e_{1}\right) d p * .
$$

Substituting for de ${ }_{1},(32)$ becomes

$$
d \pi=C_{1} G E_{p} d p *+\left(1+C_{1} G D_{y}\right)\left(p * \theta E_{p}+e_{1}\right) d p *
$$

Setting $d \pi$ equal to zero, we have

$$
\left(p * \theta E_{p}+e_{1}\right)=-\frac{C_{1} G E_{p}}{\left(1+C_{1} G D_{y}\right)}>0
$$

Equation (31) is positive by virtue of the fact that $E_{p}<0$ while $G, C_{1}>0 . \quad$ (31) Implies the following:

$$
\theta<-\frac{e_{1}}{p^{*} E_{p}}=1 / \eta_{e}^{*} \text {. }
$$

In the MM case, the profit-maximizing wedge between $p^{*}$ and $\left(-F^{\prime}\right)$ Is thus smaller than the socially optimal wedge. The MM equilibrium production and consumption levels are shown by points $M$ and $M^{\prime}$ respectively In Figure IV. With $\mathrm{p}=-\mathrm{F}^{\prime}$ as shown, $M$ must involve a higher level of $\mathrm{X}$ production than the production level at $\mathrm{S}$, the $\mathrm{SW}$ equilibrium. Indeed, $M$ must lie somewhere between the SW equilibrium and the free trade production point $A$ in Figure I. ( $\theta$ could not be negative since this would Involve negative profits given constant returns in $X$ and competitive factor markets. Producers could always realize zero profits by producing at A.) Simllarly, the social welfare level at the MM equilibrium must lie between the social optimum and free trade welfare levels.

The intuition as to why the MM equilibrium is not identical to the SW can be seen by referring back to equation (27). With $\theta=1 / n_{e}^{*}$, profits 
would be optimized with respect to world prices, and from this point of view a small change in $\theta$ would result in zero change in profits. However, a small decrease in $\theta$ from its SW level increases the domestic price of the export good (dp $>0$ ) as per the usual restrictions we have imposed on elasticities ( $E_{p}<0$ is sufficient for this result). This small improvement in $p$ increases the domestic component of the board's profits by $C_{1} d p$ without affecting forelgn profits. Thus the marketing board should maintain a distortion somewhat smaller than the welfare maximizing distortion found by solving (28). In fact, subtracting (28) from (29), at a common value of $\theta$ shows that $(d \pi-d y)=c_{1} d p$. Profits are maximized at a higher domestic price (and lower world price) for the export good than the social welfare maximizing price.

As a final point, note that both the MD equilibrium.in Figure III and the M equilibrium:In Figure IV involve a world price ratio less than the world price ratio at the SW equilibrium. The former occurs since the wedge between $p^{*}$ and $-F^{\prime}$ is the same at $D$ and $S$ (Figure III) and $-F^{\prime}$ is smaller at D than at $S$. Since forelgn welfare is a monotonically decreasing function of $\mathrm{p}^{*}$, foreigners are thus unambiguously better off with the MD and MM boards than with an optimal export tax. 


\section{Retaliation and Collusion}

The purpose of this section is to very briefly consider the implications of two countries engaging in the type of behavior modelled above. Suppose for example that both countries have MM-type marketing boards such there is only the single distortion between $p *$ and the MRT in each country. In this case, it follows from Jones (1967), Markusen and Melvin (1979), and Markusen (1981) that the forelgn offer surface can be specified as follows:

$$
e_{1}=E\left(p^{*}, \theta *\right), \quad E_{p}<0, \quad E_{\theta}<0,
$$

where $\theta *$ is the foreigner's export tax (or import tariff). The signs of $E_{p}$ and $E_{\theta}$ follow from the assumption that $i t$ is never rational to operate on the inelastic section of the foreigner's. offer curve.

In Cournot-Nash behavior of the type modelled by Johnson (1954) and Gorman (1958), each country optimizes with respect to $\mathrm{p}^{*}$ while viewing the other country's distortion as fixed. The resulting equilibrium involves a lower world real income but not necessarlly a lower real income for both countries relative to free trade (Johnson (1954), Markusen (1981)).

It is an implication of the previous section that an Marketing board will impose a smaller distortion for any level of the foreign distortion relative to the optimal export tax, given constant elasticity offer surfaces and Cournot-Nash behavior. It then follows directly from Gorman, Johnson and Markusen that the values of $\theta$ and $\theta *$ characterizing the Cournot-Nash MM equilibrlum will both be lower than the corresponding values of $\theta$ and $\theta *$ characterizing the Cournot-Nash SW equilibrium. This In turn implies that the Cournot-Nash MM equilibrium involves a higher level of world real income relative to the Cournot-Nash SW equilibrium ${ }^{6}$. 
One reaches the opposite conclusions by comparing two marketing boards that behave in a collusive fashion relative to two governments which "collude". Two marketing boards maximizing their joint profits will in general impose some distortions on the system. Two governments colluding to maximize joint welfare will achieve a Pareto optimal allocation (either free trade or free trade plus some transfer payment). Thus the cholce between export taxes and marketing boards in an interdependent, two-country setting depends in part on behavioral assumptions. 
VII. Summary and Conclusions

The purpose of this paper was to compare on efficiency grounds a profit-maximizing marketing board with the more traditional notion of an optimal export tax. Three versions of the marketing board problem were considered:

A. the board could not price discriminate between domestic and foreign customers (the $\mathbb{M N}$ board),

B. price discrimination was permitted (the MD board), and

C. for reasons of government regulation or domestic competition the board was constrained by domestic, marginal-cost pricing (the MM board).

It was shown that all three marketing board equilibria produced a level of welfare less than the social optimum level. Perhaps more worrying is the fact that only the domestic marginal-cost-pricing case is assured of producing a welfare level which is equal to or greater than the free-trade level of welfare. The most (and perhaps only) surprising result here is that the MM board is not equivalent to the optimal export tax. Despite the domestic marginal-cost pricing constraint, a profit-maximizing as opposed to a welfare maximizing agent finds $1 t$ in his interests to distort domestic prices.

Regarding the level of production of the export good, it was shown that the MM equilibrium involved production in excess of the welfare optimum level while the MD equilibrium involved a level less than the optimum level. The MN equilibrium could go either way, but a sufficient condition for production to be less than the optimum level is that domestic demand be less elastic than foreign excess demand. 
One implication of these different production levels Involves forelgn welfare. We were able to show that the $M D$ and $M$ equilibria involved lower prices for the domestic export good and thus a higher level of foreign welfare relative to the SW equilibrium. The $M$ and $M$ boards thus in a sense transfer income abroad relative to the optimal export tax. The MN board may on the other hand possibly increase the relative price of the domestic export good and thus deteriorate the welfare of both countries relative to the SW optimum.

The paper concludes with a brief discussion about retaliation and collusion in a two-country setting. Given Cournot-Nash behaviour, It was argued that two $M$ marketing boards would in fact produce a level of world welfare higher than that produced by the retaliatory imposition of export taxes. Collusive behaviour would on the other hand lead two marketing boards to a solution inferior to that achieved by two "collusive" or cooperative governments.

The case of Cournot-Nash retaliation aside, the policy Implication seems to be that marketing boards are at best a secondbest policy option. I say "at best" because the MN and MD type boards can in fact prove inferior to unilateral free trade. Suppose we then adopt a "mini-max" attitude of asking what is the worst possible outcome in each of the relevant cases. The export tax is clearly the first-best option, while the MM board is unambiguously the second-best choice. Unilateraly free trade comes third in the ranking, while the MN and MD marketing boards finish in fourth place. 
FOOTNOTES

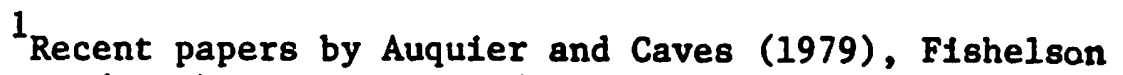
and Hillman (1979), and Brander (1980) consider closely related normative issues. The first two papers consider the optimal tariff policy for a given degree of domestic monopoly power while Brander annalyzes commercial policy in the presence of forelgn monopoly power. The positive questions considered in the present paper are in particular closely related to several of the normative issues considered by Auquier and Caves. Analogies between the two papers will be offered from time to time.

2 The MN and MD equilibria are analogous to the case and considered by Auquier and Caves where there exists a single monopolist producing the export good. Both the discriminating and non-discriminating versions are considered. They do not however, consider an equivalent of the presenct MM equilibrium.

${ }^{3}$ This type of result really goes back to Bhagwati and Ramaswami (1963) and Bhagwati (1971) and represents a simple example of the theory of distortions or the theory of the second best: removing one distortion (barriers to trade) in the presence of other distortions (domestic monopoly power) may not improve welfare. Melvin (1970) demonstrates a similar result in the presence of domestic commodity taxes.

${ }^{4}$ This indeterminacy is reflected in the results of Auquier. and Caves who note that the sign of the optimal export tax in the presence of a non-discriminating domestic monopolist is indeterminant. In their case as in ours, the result turns on the elasticity of domestic demand relative to the elasticity of foreign excess demand.

5 This finding is consistent with that of Auquier and Caves for the case of the non-discriminating monopolist. They note that if foreign demand is more elastic than domestic demand, then the optimal export tax is a subsidy while if domestic demand is more elastic, then the optimal tax may be of either sign.

6 By higher level of "world real income" I mean a world consumption bundle (and price ratio) which is revealed prefered to alternate consumption bundles (see Markusen (1980'b)). 
REFERENCES

Auquier, A. and Richard E. Caves, "Monopolistic Export Industries, Trade Taxes, and Optimal Competition Policy," Economic Journa1 89 (1979), 559-581.

Bhagwati, Jagdish, and V.K. Ramaswamt, "Domestic Distortion, Tariff, and the theory of Optimum Subsidy", Journal of Political Economy 71, (1963), 44-50.

Bhagwati, Jagdish, "The Generalized Theory of Distortions and Welfare", in Bhagwat1 et al. (editors) Trade, Balance of Payments and Growth: Essays in Honor of Charles P. Kindleberger, North Holland, Amsterdam (1971).

Bickerdike, D.F., "The Theory of Incipient Taxes", Economic Journal 16 (1906), 529-535.

Brander, James A., "Tariffs and the Extraction of Forelgn Monopoly Rents under Potential Entry", Queens University Working Paper (1980).

Fishelson, Gideon, and A. Leo Hillman, "Domestic Monopoly and Redundant Tariff Protection", Journal of International Economics 9 (1979), 47-56.

Gorman, W.M., "Tariffs, Retallation, and the Elasticity of Demand for Imports", Review of Economic Studies 25 (1958), 133-162.

Graaff, Jan de Van, "On Optimal Tariff Structures", Review of Economic Studies 16 (1949), 47-59.

Johnson, Harry G., "Optimal Tariffs and Retaliation", Review of Economic Studies 21 (1954), 142-153.

Jones, Ronald W., "International Capital Movements and the Theory of Tariffs", Quarterly Journal of Economics 81, (1967), $1-38$.

Kemp, Murray C., The Pure Theory of International Trade and Investment, Prentice-Hall, New York (1969).

Markusen, James R., "The Distribution of Galns from Bilateral Tariff Reduction", Journal of International Economics (1981), forthcoming.

Markusen, James R., "Simple General Equilibrium with a Monopolized Sector: A Comparison of Alternate Specifications", University of Western Ontario Working Paper (1980a). 
Markusen, James R., "Trade and the Gains from Trade with Imperfect Competition", Journal of International Economics (1980b), forthcoming.

Markusen, James R. and James R. Melvin, "Tariffs, Capital Mobility and Forelgn Ownership". Journal of International Economics 9 (1979), 395-410.

Markusen, James R. and James R. Melvin, "Trade, Factor Prices and the Gains from Trade with Imperfect Competition", Canadian Journal of Economics (1981), forthcoming.

Melvin, James R., "Commodity Taxation as a Determinant of Trade", Canadian Journal of Economics, 3 (1970), 389-402.

Melvin, James R. and Robert Warne, "Monopoly and the Theory of International Trade", Journal of International Economics 3 (1973), 117-134.

Polak, J.J., "The 'Optimum Tariff' and the Cost of Exports", Review of Economic Studies $19(1950-51), 36-41$.

Vandendorpe, Adolf L., "Optimal Taxation in a Model with Traded and Non-Traded Goods", Journal of International Economics 2 (1972), 232-256. 
CENIFE FOR THE STUDY OF INIERNATIONAL EOONOMIC REIATIONS

University of Western Ontario

Working Papers

8001. Robson, Arthur J. OPEC VERSUS THE VEST: A ROBUST DUCPOLY SITUATION

8002. Mckilian, John and Ewen McCann. WETFARE EFFECIS IN CUSTOMS UNIONS

8003. Leith, J. Clark. MONEY, THE BALANCE OF PAYMENIS, AND GOVEFNMENT DEBT IN A SMALL OPEN LDC: HAITI

8004. Mansur, Ashan and John Whalley. A DEOOMPOSITION ALCORITHM FOR GENERAL EQUILIBRIUM COMPUTATION VITH APPLICATION TO INTERNATIONAL TRADE MODELS

8005. Schmid, Michael. OIL, EMPLONMENT AND THE PRICE LEVEL: A MONETARY APPROACH TO THE MACROEOONOMICS OF IMPORTED INIERMEDIATE GOODS UNDER FIXED AND FLEXIBIE RATES

8006. Markusen, James R. THE DISTRIBUTION OF GAINS FROM BILATERAL TARIFF REDUCTION 8007. Markusen, James R. TRADE AND THE GAINS FHOM TRADE WITH IMPERFECT COMPETITION 8008. Markusen, James R. and James R. Melvin. TRADE, FACTOR PRICES, AND THE GAINS FROM TRADE WITH INCREASING RETURNS TO SCALE

8009. Whalley, John. AN EVALUATION OF THE RECENT TOKYO ROUND TRADE AGREEMENT THROUGA A GEINERAL EQUILIBRIUM MODEL OF TRADE INVOLVING MAJOR TRADING AFEAS.

8010. Laidler, David. MONETARISM: AN INIERPRETATION AND AN ASSESSMENT.

8011. Wonnacott. Paul and Ronald J. Wonnacott. FREE TRADE BETHEEFN THE UNITED STATES AND CAN ADA: FIFTEEN YEARS LATER

8012. Hamilton, Bob and John Whalley. OPTIMAL TARIFF CALCULATIONS IN ALTERNATIVE TRADE MODELS AND SOME POSSIBLE IMPLICATIONS FOR CURRENT WORLD TRADING ARRANGEMENTS.

8013. Wonnacott, Paul and Ronald J. Wonnacott. THE TARIFF-FOREIGN OANERSHIP-TECHNOLOGY NEXUS: TOWARDS A LESS TRUNCATED THEORY OF CANADIAN INDUSTRIAL TRUNCATION

8014. Laidler, David. INFLATION AND UNEMPLOYMENT IN AN CPEN ECONOMY - A MONETARIST VIEIT.

8015. Leith, J. Clark. AN ESSAY ON COMMERCIAL POLICY IN THE POST-IMPORT SUBSTITUTION ERA.

8016. Schmid, Michael. IEVALUATION: KEYNESIAN TRADE MODELS AND THE MONETARY APPROACH -THE ROLE OF NOAINAL AND REAL WAGE RIGIDITY-

8017. Whalley, John. INIERNATIONAL TRADE NEUTRALITY PROPOSITIONS FOR MOVEMGENIS BETHEEN 'ORIGIN/SPLIT-RATE' AND'DESTINATION/CREDIT' TAX BASES.

8018 Whalley, John and Bernard Yeung. EXIERNAL SECTOR 'CLOSING' RULES IN APPLIED GENERAL EQUIIIBRIUM MODFIS.

8019. forthcoming 
8020. Markusen, James R. MULTINATIONALS AND THE GAINS FROM TRADE: A THEORETICAL ANALYSIS BASED ON ECONOMIES OF MULTI-PLANT OPERATION.

8021. Conlon, R.M. TRANSPORT COST AND TARIFF PROTECTION OF AUSTRALIAN AND CANADIAN MANUFACTURING: A COMPARATIVE STUDY.

8022. Markusen, James R. THE HELFARE AND ALLOCATIVE EFFECTS OF EXPORT TAXES VERSUS MARKETIING BQARDS. 